\title{
EMPLOYMENT IMPLICATIONS OF ECONOMIC LIBERALIZATION: ARDL BASED EVIDENCE FROM PAKISTAN
}

\author{
Muhammad Abdullah \\ Assistant Professor, Department of Economics, \\ University of Sahiwal, Sahiwal. Pakistan \\ mabdullah@uosahiwal.edu.pk \\ Ayza Shoukat \\ Lecturer, Department of Economics, \\ University of Sahiwal, Sahiwal. Pakistan \\ ayzashoukat@uosahiwal.edu.pk \\ Hafsah Batool \\ Lecturer, Department of Economics, \\ Lahore College for Women University, Lahore. Pakistan \\ batooleconomist@gmail.com
}

\begin{abstract}
The current study attempts to investigate whether economic liberalization influences employment in Pakistan or not. Despite the traditional analysis, our study has employed the multiple indicators of economic liberalization (trade liberalization, foreign direct investment, and remittances) and checked the effect of each indicator on the employment level. Time series annual data for the period 1980 to 2018 has been used for empirical analysis. After checking for the stationarity of data, the study proceeds with the ARDL approach. The empirical results of the study have proved that employment is sensitive to each indicator of economic liberalization. All indicators of economic liberalization seem to have a positive effect on the employment level in Pakistan's economy. They are also statistically significant both in the long run and short run. The provision of public infrastructure also promotes increased employment levels in Pakistan. The government should take policy measures for promoting free trade, encouraging foreign inflows, exchange rate deregulation, and liberalizing markets.
\end{abstract}

Keywords: Employment, Trade Openness, Remittances, Foreign Flows, Public Investment

\section{INTRODUCTION}

The developments in the global economy have radiated the economies with the beam of economic cooperation in the era of economic liberalization. Along with the other factors, economic liberalization has bestowed this edification more than any other component of commercial policy. Economic liberalization is a broader term that pertains to the limited role of government and restricting the intervention regarding trade and foreign inflows. This philosophy affirms the reforms for the development as propagated by the International Monetary Fund (IMF) as well as the World Bank, promoting free trade, encouraging foreign economic inflows, exchange rate regulation, and liberalizing markets (Bhalotra, 2003). Concisely, it objectifies economic development while restricting domestic controls at the same time.

Economic liberalization involves several procedures focusing on public sector/ government policies. More generally, it is a process of deregulation (flexible exchange rates, encouraging foreign flows and free price mechanism), encouraging trade openness and denationalization of the public sector (Woodward, 1992). Since 1970, underdeveloped economies have been relying on IFIs (International Financial Institutions) to deal with internal financial challenges. In this regard, the role of economic liberalization remained fundamental and expectations of utmost economic growth along with the poverty alleviations were there (Dawson, 2005; Billmeier \& Nannicini, 2013). Therefore, the public policies have been channeled towards a free economy or laissez-faire promoting marketoriented economic structures (i.e. market forces were responsible for the distribution of resources as well as for economic activity).

The fruits of economic liberalization have been realized to the world more fully in the past few decades with the introduction of economic integration along with international trade. There are 
many advantages associated with economic liberalization, which includes an increased level of domestic and foreign competition, accumulation of capital stock, increased efficiency and productivity, enhanced employment opportunities and technological advancements (Bhalotra, 2003; Bustos, 2009; Nataraj, 2011; Awuah \& Amal, 2011 \& Asghar et al., 2014). These adjustments pave the road to economic developments. Therefore, economic liberalization and economic development go side by side. Thus, the policies for sustainable economic development cannot be separated from economic liberalization.

The global market economy has witnessed a large number of market-oriented moves like regional economic integration along with foreign assistance. Pakistan is one of those economies that are experiencing economic integration as well as foreign economic assistance (i.e. CPEC and remittances). Pakistan was indulged in the process of economic liberalization (both trade and financial liberalization) during the decade of 1980s. During this period, Pakistan's economy was trying to devise efficient policies to establish macroeconomic stability, international trade reforms and sound financial markets (Mujahid \& Zeb, 2016). In this regard, the major policy surge to export promotion took place from the import substitution policy. Moreover, the tariff reforms were also introduced as the tariff was reduced to 10 percent from 17 percent in 1987 (Zaidi, 2015). Besides, to attract foreign investment, the government has granted complete ownership rights in nearly all industries. Various fiscal incentives, like tax holidays and tariff cut downs were also introduced. In 1995, a flexible exchange rate system had been promoted along with the cuts in custom duty (Hye et al., 2014).

The decade of 2000 and ahead has been recognized as the period of economic liberalization because Pakistan has experienced numerous liberating policies during this period. These policies were promoting free trade, deregulation in the market economy and encouraging the local investors by reducing the cost of business. As a result, these policies yielded macroeconomic stability in terms of rate of interest, rate of inflation and exchange rate. Along with this, the importance of the services sector was highlighted for the first time and trade in the services sector has also been promoted. From 2003 to 2008, Pakistan's economy has followed an inclusive trade policy. As a consequence, the economy experienced advanced economic growth by a reduction in poverty and unemployment simultaneously. Besides, the economy underwent a prosperous period of economic integration through free trade and foreign investment inflows (Mujahid \& Zeb, 2016). In 2013, the initiative of the economic corridor with China has opened new doors of economic liberalization in Pakistan. China-Pak Economic Corridor (CPEC) is a package of huge foreign investment, technological advancements, employment and business opportunities for Pakistan (Javaid, 2016). This project is an outstanding example of economic liberalization by promoting mutual trade, flourishing businesses, foreign inflows, economic prosperity through cost reduction, addressing energy issues, targeting unemployment and facilitating labor mobility across the borders (Kanwal et al., 2019). The economy of Pakistan is expected to be liberalized even more after the completion of this project.

The current study has few limitations: we are following a case study of Pakistan's economy only; the study has obtained secondary data for the 1980 to 2018 period and finally, as fewer studies are available in case of Pakistan addressing the impact of economic liberalization on employment by using multiple indicator approach; therefore, we have limited scope of discussion. The future course of the study could be employing regional data for various countries and implications of the results could be broadened. The rest of the paper is organized as; section 2 summarizes the related literature, section 3 is dedicated for data and methodology, results are discussed in section 4, and section 5 presents a conclusion followed by necessary policy implications.

\section{REVIEW OF LITERATURE}

The endogenous growth theory suggests that economic liberalization tends to facilitate the process of economic development, particularly in underdeveloped countries. The immediate advantages of economic integration lead to employment creation, accumulation of human capital, foreign inflows and stable macroeconomic conditions. Also, in the long run, the technology drawn from developed nations allow the developing countries to excel in research and innovation, acquire economies of scale, stabilize the domestic price, evolving efficiency in production and; therefore, increase in derived demand for labor which eventually enhances the employment opportunities (Mujahid \& Zeb, 2016). To check the employment implications of economic liberalization, the current study has incorporated three indicators of economic liberalization; trade liberalization, foreign direct investment 
(FDI) and remittances. Therefore, we have divided empirical economic literature into the following three sub-sections.

\section{Trade Liberalization}

International trade theory depicts the impact of free trade on employment in two ways, one is the scale effect and the other is the substitution effect. The scale effect postulates that export demand is increased as a result of higher integration of countries through trade, which in turn increases the labor demand in the home country and new jobs are created. Whereas, higher international trade-led import competition will encourage the production in domestic substitute industry. As a result, new employment opportunities would be created in the domestic imports substitute industry (Martin, 1976).

According to a study by Papageorgiou et al., (1990), there have been numerous advantages associated with trade openness particularly for developing countries. The study critically evaluated the case of 19 underdeveloped countries for 36 different episodes of free trade and ascertain the advantages for economic development in the long run. Even in the short run, free trade is promising in terms of economic growth as well as curtails unemployment in both the agriculture and manufacturing sectors. The study further added that trade openness also boosted agricultural productivity along with employment creation.

Lee and Vivarelli (2006) conducted a study on selected liberalized economies to check the effects of liberalization on employment and wage structure. These economies including Brazil, China, India, Malaysia and Mexico, who have been all exhibiting growth in free trade along with the most benefiting economies from free trade amongst developing countries. In China, India and Malaysia, the positive effects of free trade were tremendous as compared to the other economies. The employment creation and wage structure have significantly improved in these three economies. Besides, the deregulation policy proved to be more favorable for semi-skilled and unskilled workers as compared to the skilled workforce. It was because employment creation was concentrated more in exportoriented industries than the other industries. After all, export-oriented industries primarily hire semiskilled workers. Moreover, the import-competing industries have also been creating job opportunities to compete in the global market. However, trade growth did not positively affect the employment and wage structure in Brazil and Mexico because of the absence of initial favorable conditions like highly inadequate wealth distribution and macroeconomic instability.

Kien and Heo (2009) found the positive and significant impact of trade liberalization on the derived demand of industrial labor for Vietnam using a system generalized method of moments model for the period of 1999 to 2004. Asghar et al., (2014) has explored the effects of trade liberalization on employment in the South Asian Association for Regional Cooperation (SAARC) countries in the context of the Free Trade Agreement (FTA) regime. The study suggested that the effects of trade liberalization on employment in advanced countries are significantly positive, wherein in the case of developing countries, these effects are negative. The impact of economic globalization on employment has been empirically tested by Awad and Youssof (2016). By employing the ARDL model, the study has examined the data from 1980 to 2014 of the Malaysian economy. The empirical results suggest that economic globalization has significantly and positively contributed to employment creation in Malaysia.

Van and Tran (2017) have empirically tested the impact of rising international trade on employment in Vietnam. The study has employed a fixed effect quintile approach by including the heterogeneous characteristics of firms. Empirical findings of the study suggest that firms with high employment percentile have shown the positive impact of trade on job creation in Vietnam.

\section{FDI}

The foreign influx is known for its impact on the economic prosperity of underdeveloped countries. Amongst all, foreign direct investment is considered to be the most favorable contributor for economic growth as well as to economic liberalization. Economic theory has postulated mixed outcomes of FDI for the economy. The neoclassical theory of growth suggested that FDI affects the economic performance of an economy but in the short run only. Whereas, the new theory of growth suggests that long-run goals of economic prosperity like employment generation and technological progress can be achieved through FDI (Hsiao and Hsiao, 2006). Also, it urges to create employment 
opportunities, channel technological progress, increased competition and economic development in host economies (Wang \& Blomstrom, 1992; De Mello, 1999).

Jayaraman and Singh (2007) examined the relationship between FDI and employment in Fiji. The study collected the data for thirty years. For empirical testing, the study adopted a multivariate modeling strategy. The empirical analysis suggested that in the short run, there exists a unidirectional causality from FDI to GDP. However, in the long run, FDI cause to create employment. There also existed the unidirectional causality from FDI to employment creation in Fiji.

The impact of FDI on employment creation has been also empirically tested by Rizvi and Nistat (2009). The study investigated the case of three emerging economies (i.e. China, India and Pakistan) from 1985 to 2008. Panel data methodology has been applied to test the hypothesis. The study concluded that FDI did not contribute to job creation in these economies directly. However, the indirect impact of FDI on employment cannot be denied. Moreover, the study suggested other policy measures other than attracting FDI to improve employment conditions in these countries.

The Malaysian economy has been investigated for the relationship between FDI and unemployment by Shaari et al., (2012). The study took into account the period of 1980 to 2010 . Ordinary Least Square (OLS) analysis has been conducted for empirical verification of the existence of the said relationship. Empirical results showed that FDI act as a key factor to reduce unemployment in Malaysia. The study further added that FDI also positively and significantly affected economic growth during this period.

Muck et al., (2013) analyzed the FDI and unemployment nexus for seven underdeveloped countries. Panel data analysis has been conducted on a data set from 1981 to 2009. Empirical analysis showed that in the long run, FDI has strong and diversified effects on unemployment. The study suggested that positive outcomes can be achieved in developing countries with efficient policy implementation at the macroeconomic level. The study further added that Greenfield investments can bring about huge employment opportunities in the host countries. Aqil et al., (2014) have empirically investigated the determinants of unemployment in Pakistan. The study enlists four major determinants including inflation, the growth rate of population, FDI and GDP. Empirical results suggest that only FDI and the growth rate of the population are significantly and negatively affecting unemployment in Pakistan.

Bekhet and Mugableh (2016) have empirically verified the effects of inward FDI on employment in Malaysia in different economic sectors. By employing the data for the period 1972 to 2012, the study proceeds with the time series analysis. Moreover, causality has also been tested. Empirical results suggest that inward FDI and employment are co-integrated in the long run, whereas there exists unidirectional causality from FDI to employment in Malaysian economic sectors.

Tsaurai (2018) has established the employment effects of FDI for Brazil, Russia, India, China and South Africa (BRICS). The study employed panel data analysis for the 1994-2014 period. The study suggests that the FDI significantly and positively contributes to the employment in BRICS economies. Besides, the impact of FDI on employment can be accelerated by targeting macroeconomic policies regarding human capital and financial development in BRICS.

\section{Remittances}

The significance of remittances for the economy cannot be denied, particularly for a developing country like Pakistan. Remittances can prove to be a driver of economic activity. The impact of remittances on employment creation is not direct but indirect. Employment opportunities are created by increased demand and higher economic growth levels. Fewer empirical studies have analyzed the chain of employment creation through remittances.

Burney (1987) investigated the impact of remittances from Middle East countries on the GDP growth of Pakistan by taking into account the time series data. The study suggested that remittances directly and positively affected the GDP growth rate. Moreover, remittances affect unemployment and poverty negatively by facilitating the process of investments in the recipient country. Not only the GDP growth but the socio-economic indicators of the recipient economies tend to improve. Remittances increases investment as well as consumption patterns. Due to increased investment initiatives as a result of remittances inflow, the creation of new jobs along with poverty reduction improves the economic conditions of the transitional economies (Adam, 1998). 
León-Ledesma and Piracha (2004) have analyzed the effects of remittances in central and east European countries. The study has empirically studied the data of eleven economies from 1990 to 1999. The study suggests that the outcomes of remittances on employment are conditional that how the productivity and entrepreneurial decisions are responding to these remittances. The empirical results proved that the positive effects of remittances on employment are confirmed. Remittances also smoothed the process of employment creation through investment both directly and indirectly.

Raza (2008) empirically tested the effects of remittances and migration on employment in Pakistan. The study incorporates both micro as well as macro aspects of the underlined. The empirical results suggested that both migration and remittances positively affect employment in Pakistan but these effects are indirect.

Shera and Meyer (2013) have examined the relationship of remittances with the economic growth of developing countries. The study employed data of 21 developing economies for the period 1992 to 2012. By employing panel data methodology, the study postulates that worker remittances positively affecting the per capita GDP of recipient countries.

Yoshino et al., (2018) have examined the developing Asian economies for the impact of international remittances on poverty. The study employed the data for the 1980 to 2014 period. By using OLS, the study used three different indicators of poverty; poverty severity ratio, poverty headcount ratio and poverty gap. Empirical findings of the study propose that international remittances have a direct and significant effect on poverty reduction in developing Asian economies. Further, remittance and trade openness can accelerate the process of poverty reduction in developing economies of Asia.

Literature shows that different studies used a single indicator of economic liberalization to determine the relationship between economic liberalization and employment. The employment implications of economic liberalization have not been explored much by using multiple indicators simultaneously. Fewer studies are addressing the phenomenon and these studies are even rare in the case of Pakistan. Bridging this gap, the current study intends to investigate the relationship between economic liberalization and employment in the case of Pakistan by taking into account the multiple indicators of economic liberalization like FDI, trade openness and remittances along with some control variables.

\section{DATA AND METHODOLOGY}

This study has utilized data for the duration of 1980 to 2018 sourced from World Development Indicators (WDI) 2019, the online database of the World Bank and Pakistan Economic Survey (various issues). The literature review in the previous section predicts various factors affecting the employment level in an economy. The main concern of the present study is to examine the implications of economic liberalization for employment in the case of Pakistan. The null hypothesis for this is that there exists no long-run relationship between economic liberalization and employment, whereas the alternative hypothesis states that there exists a long-run relationship between economic liberalization and employment. The current study expects the existence of the long-run and positive relationship between the indicators of economic liberalization and employment creation. For this purpose, this study has considered the following model close to the derived demand equation used by Kien and Heo (2009).

$$
E M P=F(T L, F D I, R E M T, P I, P O P)
$$

Where EMP is employment level, TL is trade liberalization; FDI foreign direct investment, REMT is used for remittances, PI is public investment, POP is population. The preceding functional form is expressed as the following econometric model:

$$
L n E M P_{t}=\alpha_{0}+\beta_{1} T L_{t}+\beta_{2} F D I_{t}+\beta_{3} R E M T_{t}+\beta_{4} L n P I_{t}+\beta_{5} P O P G_{t}+\varepsilon_{t}
$$

(2)

The dependent variable is the level of employment which is measured by the employed workforce out of the total workforce. Trade liberalization is measured as net exports as a percentage of GDP. The other indicator of economic liberalization is FDI which is taken into account as net foreign inflows as a percentage of GDP. Remittances are measured through worker's remittances as a percentage of 
GDP. The other supporting variables like public investment are measured through the public capital stock. The population growth rate is used to capture the effect of population on employment.

\section{EMPIRICAL RESULTS AND DISCUSSION}

The problem of unit root is common in time-series data. A time series containing unit root exhibits non-constant mean and variance and if this problem is not addressed, then the empirical analysis would yield spurious results. Therefore, we tested our data set for the unit root by using Augmented Dickey-Fuller (ADF) test. Table-1 shows the results of ADF test statistics.

Table-1. Unit Root Testing

\begin{tabular}{lccccc}
\hline \multirow{2}{*}{ Variables } & \multicolumn{2}{c}{ At Level } & \multicolumn{2}{c}{ At $\mathbf{1}^{\text {st }}$ Difference } & \multirow{2}{\text{Integration}}{ Order } \\
\cline { 2 - 4 } & ADF Stat & P-Value & ADF Stat & P-Value & \\
LnELF & -0.5189 & 0.8758 & $-5.5504^{*}$ & 0.0001 & $\mathrm{I}(1)$ \\
TL & -1.7263 & 0.4101 & $-7.7739^{*}$ & 0.0001 & $\mathrm{I}(1)$ \\
FDI & $-2.8762^{* *}$ & 0.0477 & -4.0253 & 0.0035 & $\mathrm{I}(0)$ \\
REMI & -2.1054 & 0.2438 & $-3.9986^{*}$ & 0.0032 & $\mathrm{I}(1)$ \\
LnPI & $-3.9746^{*}$ & 0.0040 & -4.8559 & 0.0004 & $\mathrm{I}(0)$ \\
POPG & -2.6010 & 0.1026 & $-4.8307^{*}$ & 0.0023 & $\mathrm{I}(1)$ \\
\hline
\end{tabular}

$*, * *$ level of significance, $1 \%$ and $5 \%$ respectively

The ADF test results showed the mixed order of integration; some series are stationary at level $\mathrm{I}(0)$ and the others are stationary at the first difference I(1). In this situation, we can determine the existence of a long-run relationship between variables of economic liberalization and employment by using the technique developed by Pesaran et al., (2001) and considered appropriate for the analysis in case of mixed order of integration. This technique is known as Auto Regressive Distributive Lag (ARDL) approach. Table-2 represents the empirical results of ARDL.

\section{Table-2. ARDL Approach Results}

\begin{tabular}{lcl}
\hline \multicolumn{3}{c}{ Critical Value Bounds } \\
\hline Significance & Lower Bound & Upper Bound \\
$1 \%$ & 3.41 & 4.68 \\
$2.50 \%$ & 2.96 & 4.18 \\
$5 \%$ & 2.62 & 3.79 \\
$10 \%$ & 2.26 & 3.35 \\
\hline F-statistic & 9.88 & $\mathrm{~K}=5$ \\
\hline
\end{tabular}

ARDL approach is followed by bound testing which is generally reviewed through Wald statistics. Table-2 indicates that F-statistics (9.88) is bigger than the upper Bound value i.e. 4.68 at a 1 percent significance level. This supports our hypothesis of the presence of a long-run relationship between economic integration and employment level. Since the existence of co-integration is established through the ARDL technique by using the Bound test. The next step is to achieve long-run coefficients which are presented below.

Table-3. Long Run Coefficients for the Dependent Variable LnELF

\begin{tabular}{lcccc}
\hline Variable & $\begin{array}{c}\text { Coefficient } \\
\text { Value }\end{array}$ & Standard Error & $\begin{array}{c}\text { Calculated } \\
\text { values of t }\end{array}$ & Probability \\
\hline TL & $0.0033^{* *}$ & 0.0016 & 2.0692 & 0.0475 \\
FDI & $0.0339^{* *}$ & 0.0141 & 2.4035 & 0.0307 \\
REMI & $0.0588^{*}$ & 0.0240 & 2.4500 & 0.0232 \\
Ln PI & $0.1219^{*}$ & 0.0499 & 2.4450 & 0.0283 \\
POPG & $-0.4942^{*}$ & 0.0645 & -7.6667 & 0.0000 \\
\hline
\end{tabular}




\begin{tabular}{|c|c|c|c|c|}
\hline C & $11.3479 *$ & 01799 & & \\
\hline
\end{tabular}

The results showed in Table-3, prove the positive association between economic liberalization and employment in Pakistan. Indicators of economic liberalization like trade liberalization (TL),

\begin{tabular}{|l|c|c|c|}
\hline \multicolumn{2}{|l|}{ Table-5 Assumptions Verifications Diagnostic } & & \\
\hline Diagnostic Test For & Test Name & F. Statistics & Probability \\
\hline Model Specification Test & Ramsey RESET Test & 0.3057 & 0.4977 \\
\hline Normality Test & Jarque-Bera Statisics & 0.4399 & 0.8025 \\
\hline Serial Correlation LM Test & Breush-Godfrey Test & 2.6858 & 0.1086 \\
\hline Heteroskedasticity Test & ARCH Test & 1.8290 & 0.1792 \\
\hline Heteroskedasticity Test & Breusch-Pagan-Godfrey & 0.6203 & 0.8312 \\
\hline
\end{tabular}

foreign direct investment (FDI) and remittances (REMI) along with the public investment (PI) are positively and significantly affecting the employment level. Whereas, population growth is negatively but significantly affecting employment in Pakistan.

Table-4. Dynamics in the Short Run for the Dependent Variable: D(LNELF)

\begin{tabular}{lcccc}
\hline Variable & $\begin{array}{c}\text { Coefficient } \\
\text { Value }\end{array}$ & $\begin{array}{c}\text { Standard } \\
\text { Error }\end{array}$ & $\begin{array}{c}\text { Calculated } \\
\text { values of t }\end{array}$ & Probability \\
\hline D(TL) & $0.0028^{*}$ & 0.0012 & 2.2146 & 0.0439 \\
D(FDI) & -0.0082 & 0.0082 & -1.0055 & 0.3317 \\
D(FDI(-1)) & -0.0112 & 0.0091 & -1.2258 & 0.2405 \\
D(FDI(-2)) & -0.0115 & 0.0089 & -1.2969 & 0.2156 \\
D(FDI(-3)) & -0.0170 & 0.0108 & -1.5673 & 0.1394 \\
D(REMI) & $0.0132^{*}$ & 0.0037 & 3.5434 & 0.0032 \\
D(REMI(-1)) & $-0.0129^{*}$ & 0.0042 & -3.0353 & 0.0089 \\
D(REMI(-2)) & -0.0022 & 0.0036 & -0.6165 & 0.5475 \\
D(REMI(-3)) & $-0.0187^{*}$ & 0.0036 & -5.1480 & 0.0001 \\
D(LnPI) & $-0.2775^{*}$ & 0.0733 & -3.7881 & 0.0020 \\
D(LnPI (-1)) & $-0.1709^{* *}$ & 0.0678 & -2.5226 & 0.0244 \\
D(POPG) & $-1.4121^{*}$ & 0.2878 & -4.9070 & 0.0002 \\
D(POPG(-1)) & $1.5177^{*}$ & 0.2493 & 6.0868 & 0.0000 \\
ECT(-1) & -0.8280 & 0.1179 & -7.0215 & 0.0000 \\
\hline$*$
\end{tabular}

$*, * *$ level of significance at $1 \%$ and $5 \%$

The short-run dynamics suggest that trade liberalization (TL) and remittances (REMI) are statistically significant and showed a positive impact on employment, where others are statistically insignificant. However, in the short run, significance of the ECT term is our prime apprehension. The negative and statistically significant ECT term, affirms the presence of a relationship among the concerned variables in the long-run. Whereas the coefficient value of ECT reflects the promptness of convergence towards equilibrium.

According to the results reported in Table-4, the first lag of the ECT term is not only negative but also significant along with a significant speed of convergence. Based on empirical results, we can conclude that employment, in the case of Pakistan, is positively sensitive to economic liberalization in the long run as well as in the short run.

In Table-5, the results of diagnostic tests have been reported. According to the results, our model is well and correctly specified. It is free from the problems of heteroscedasticity and serial correlation. Moreover, the residuals are normally distributed.

CONCLUSION AND POLICY RECOMMENDATIONS 
The empirical results of the study have supported the view that economic liberalization increases employment. Despite the traditional analysis, our study has taken into account the multiple indicators of economic liberalization and checked the effects of each indicator on employment level. The importance of free trade, foreign direct investment and remittances for employment in Pakistan have been highlighted through this study.

Pakistan needs to follow the trajectory of the open economy to promote not only free trade but also encourage foreign investment. Both free trade and foreign investment bring about the competition that leads to efficiency in the production of local industry as well as the inflow of foreign exchange. To attract foreign investors, the basic needs of infrastructure must be fulfilled along with addressing the external and internal security threats. Remittances are also a source of economic growth and employment, and can be used to improve the balance of payments. To provide the advanced facilities for migrants to send their earnings to the home country is mandatory. By improving basic infrastructure services and law and order situation at home, these migrants can venture the businesses in the home country, which further multiplies the employment and business activity.

\section{REFERENCES}

Adams, R.H. (1998). Remittances, investment and rural assets accumulation in Pakistan. Economic Development and Cultural Change, 47(1), 155-173.

Akbar Zaidi, S. (2015). Issues in Pakistan's economy: A political economy perspective. Oxford University Press Catalogue.

Aqil, M., Qureshi, M.A., Ahmed, R.R., \& Qadeer, S. (2014). Determinants of unemployment in Pakistan. International Journal of Physical and Social Sciences, 4(4), 676-682.

Asghar, M., Yousuf, M., \& Ali, S. (2014). Impact of trade liberalization on employment: review of SAARC countries. Applied Sciences and Business Economics, 1(1), 49-55.

Awad, A., \& Youssof, I. (2016). The impact of economic globalization on unemployment: The Malaysian experience. The Journal of International Trade and Economic Development, 25(7), 938-958.

Awuah, G.B., \& Amal, M. (2011). Impact of globalization: the ability of less developed countries firms to cope with opportunities and challenges. European Business Review, 23(1), 120-132.

Bekhet, H.A., \& Mugableh, M.I. (2016). Blueprinting the equilibrium relationships between inward FDI and employment in the Malaysian economic sectors: time series models approach. Global Business and Economics Review, 18(2), 136-150.

Bhalotra, S.R. (2003). The impact of economic liberalization on employment and wages in India. International Labor Organization, 121-132.

Billmeier, A., \& Nannicini, T. (2013). Assessing economic liberalization episodes: A synthetic control approach. Review of Economics and Statistics, 95(3), 983-1001.

Burney, N.A., \& Ahmad, M.A. (1987). Worker's remittances from the Middle East and their effect on Pakistan's economy. The Pakistan Development Review, 26(4), 745-763.

Bustos, P. (2009). Trade liberalization, exports and technology upgrading: Evidence on the impact of MERCOSUR on Argentinean firms. American Economic Review, 101(1), 304-40.

Das, A., Banga, R., \& Sahu, P.K. (2011). Impact of remittances on poverty in developing countries. Technical report, United Nations.

Dawson, A. (2005). The socioeconomic effects of economic liberalization revisited: A case for democracy. McGill social statistics masters working paper series, series 2005-3.

De Mello, LR. Jr., (1999). Foreign direct investment-led growth evidence from time series and panel data, Oxford Economics Papers, 51, 133-151.

Hsiao, F.T. \& Hsiao, M.W. (2006). FDI, exports, and GDP in East and Southeast Asia - panel data versus time-series causality analyses. Journal of Asian Economics, 17(6), 1082-1106.

Hye, Q.M.A., Lau, W.Y., \& Tourres, M.A. (2014). Does economic liberalization promote economic growth in Pakistan? An empirical analysis. Quality and Quantity, 48(4), 2097-2119.

Javaid, U. (2016). Assessing CPEC: potential threats and prospects. Journal of the Research Society of Pakistan, 53(2), 254-269. 
Jayaraman, T. K., \& Singh, B. (2007). Foreign Direct Investment and Employment Creation in Pacific Island Countries: an Empirical Study of Fiji (No. 35). ARTNeT Working Paper Series.

Kanwal, S., Chong, R., \& Pitafi, A.H. (2019). China-Pakistan economic corridor projects development in Pakistan: Local citizen's benefits perspective. Journal of Public Affairs, 19(1), 1-12.

Kien, T.N., \& Heo, Y. (2009). Impacts of trade liberalization on employment in Vietnam: a system generalized method of moments estimation. The Developing Economies, 47(1), 81-103.

Lee, E., \& Vivarelli, M. (2006). The social impact of globalization in the developing countries. Institute of Labor Economics, Discussion Paper No. 1925.

León-Ledesma, M., \& Piracha, M. (2004). International migration and the role of remittances in Eastern Europe. International Migration, 42(4), 65-83.

Martin, J.P. (1976). Variable factor supplies and the Heckscher-Ohlin-Samuelson model. The Economic Journal, 86(344), 820-831.

Mucuk, M. \& Demirsil, M.T. (2013). The effect of Foreign Direct Investment on Unemployment: Evidence from Panel Data for seven developing countries. Journal of Business, Economics and Finance, 2(3), 53-66.

Mujahid, N., \& Zeb, A. (2016). Nexus between trade liberalization and unemployment: an investigation in the context of Pakistan. International journal of African and Asian Studies, 28, 50-55.

Nataraj, S. (2011). The impact of trade liberalization on productivity: Evidence from India's formal and informal manufacturing sectors. Journal of International Economics, 85(2), 292-301.

Papageorgiou, D.. Choksi, A. \& Michaely, M. (1990). Liberalization of foreign trade in developing countries: The lessons of experience. World Bank, Washington, DC. Retrieved from; http://documents.worldbank.org/curated/en/824261468765268505/Liberalizing-foreign-tradein-developing-countries-the-lessons-of-experience.

Pesaran, M.H., Shin, Y. \& Smith, R.J., (2001). Bounds testing approaches to the analysis of level relationships. Journal of Applied Econometrics, 16(3), 289-326.

Raza, A. (2008). The effect of remittances on employment in Pakistan. Available at SSRN 1253162.

Rizvi, S.Z.A. \& Nishat, M., 2009. The Impact of Foreign Direct Investment on Employment Opportunities: Panel Data Analysis: Empirical evidence from Pakistan, India and China. The Pakistan Development Review, 48(4), 841-851.

Shaari, M.S., Hussain, N.E. \& Halim, M.S.B.A., 2012. The Impact of Foreign Direct Investment on the Unemployment Rate and Economic Growth in Malaysia. Journal of Applied Sciences Research, 8(9), 4900-4906.

Shera, A., \& Meyer, D. (2013). Remittances and their impact on Economic growth. Periodica Polytechnica Social and Management Sciences, 21(1), 3-19.

Tsaurai, K. (2018). Exploring the employment effect of FDI in BRICS: does conditionalities matter?. Acta Universitatis Danubius. Economica, 14(3), 86-103.

Van Ha, H., \& Tran, T.Q. (2017). International trade and employment: A quantile regression approach. Journal of Economic Integration, 32(3), 531-557.

Wang, J.Y. \& Blomstrom, M., 1992. Foreign investment and technology transfer: a simple model. European Economic Review, 36(1), 137-155.

Woodward, D. (1992). Debt, adjustment, and poverty in developing countries. Martin's Press.

Yoshino, N., Taghizadeh-Hesary, F., \& Otsuka, M. (2018). International remittances and poverty reduction: evidence from developing Asia. Journal of Comparative Asian Development, $17(2), 21-42$. 